\title{
An insight into artisanal leather making in Ghana
}

\author{
Miriam Appiah-Brempong ${ }^{1^{*}} \mathbb{D}$, Helen M. K. Essandoh ${ }^{1}$, Nana Yaw Asiedu², Samuel Kwame Dadzie ${ }^{1}$ and \\ Francis Warings Yao Momade ${ }^{3}$
}

\begin{abstract}
The production of leather from animal skins and hides through tanning processes began in the pre-historic ages. Despite the origination of new leather making techniques such as chrome tanning which is being employed extensively today, the traditional method of leather production primarily through vegetable tanning is still being practised mostly in artisanal tanneries in developing nations including Ghana. Artisanal leather making, thus, contributes beneficially to rural livelihood. Nevertheless, the growth of this sector has been stifled by the lack of innovative technologies to enhance productivity. This challenge could be partly linked to the knowledge gap on the scientific principles governing artisanal leather production processes. This study, therefore, elaborates on various process steps and materials employed in traditional leather making in Ghana and the scientific principles underlying each of the processes. It also makes a comparison between traditional and modern leather manufacturing processes and identifies knowledge and technological gaps which would inspire in-depth scientific research into artisanal leather making.
\end{abstract}

Keywords: Artisanal leather making processes, Modern-day leather manufacturing, Animal skin/hide, Tannery, Pre-tanning, Tanning, Post-tanning

\section{Introduction}

From ancient times, the skins and hides of animals have played indispensable roles in the sustenance of human life. They were used extensively in making warm clothing, shoes and tents. The skins and hides were, however, observed to rot rapidly particularly in hot regions whilst in cold regions, they became rather rigid after losing their flexibility [1]. Since then various tanning mechanisms have been devised in transforming these biodegradable skins/hides into leather; a water-proof material with high durability and flexibility [2].

For centuries, leathers have been manufactured principally through the vegetable tanning technique. This method utilizes tannins as tanning agents in converting skins/hides into leather. Tannins are extracts largely

\footnotetext{
* Correspondence: esisamiriam@yahoo.co.uk

${ }^{1}$ RWESCK, Department of Civil Engineering, College of Engineering, Kwame Nkrumah University of Science and Technology, Kumasi, Ghana Full list of author information is available at the end of the article
}

composed of phenolic compounds obtained from different parts of plants such as the barks, roots, fruits and leaves [3]. This artisanal way of leather production has been carried out in open pits using very simple tools and manual procedures [4].

However, over the years, the leather industry has seen significant modernization in its processes. Leather production in modern times makes use of sophisticated machinery, equipment, diverse chemicals and modified practices in carrying out the fabrication processes in well-structured factories [4]. Numerous studies have been centred on modern leather manufacturing processes which has led to its significant advancement. As a result, the traditional method of tanning, the vegetable tanning technique has been overtaken by chrome tanning in modern leather production which is currently practised in more than $90 \%$ of the world's tanneries [5].

Despite this massive progress made in the leather making industry, traditional methods for leather production is 
still practised by artisans in developing nations including Ghana. It is a source of livelihood for most rural folks in less developed countries. However, the growth of this sector has been stifled by the lack of innovative technologies which has resulted in the production of low quality leathers. This challenge could be partly due to the lack of understanding of the scientific principles underlying artisanal leather manufacturing. The few studies that have been performed on artisanal leather production as practised in different countries which include the works of Gebremichael [6], Wemegah [7] and Zaruwa \& Kwaghe [8] only gave a narrative description of the leather making procedures. There is, therefore, a paucity of knowledge on the scientific principles underpinning the processes and materials involved in artisanal leather making. Enhanced knowledge and a deepened understanding of the scientific background of artisanal leather making processes will aid in the identification, development and adoption of suitable, green innovative technologies and best practices, optimization of the various processes involved, production of good quality indigenous leathers that would meet international standards, identification and characterization of the various tannery wastes and development of appropriate waste management schemes. Ultimately, the sector will become attractive particularly to the youth which would result in a decrease in the unemployment rate in the country.

This review is, therefore, aimed at elaborating on the traditional leather making techniques in Ghana and probing into the scientific basis, identifying knowledge and technological gaps in the artisanal leather production processes and making comparison between artisanal and modern leather manufacturing processes. It is hoped that this review will stimulate further scientific research into artisanal leather production.

\section{Overview of leather making processes in artisanal tanneries}

Leather production in Ghana is said to have commenced more than a century ago. Tanners in the northern sector of the country are the historical custodians of artisanal leather manufacturing. The tradition was first introduced to them by some tanners who migrated from Northern Nigeria. Later, the art of artisanal leather making began in two other regions in the country, namely, Ashanti and Greater Accra Regions [9, 10].

Generally, leather making activities are carried out in the open space. There are, however, poorly constructed small wooden sheds at the tanneries which house the skins, leathers and other working materials (Fig. 1). These shanties also shelter the tanners during unfavourable weather conditions. Animal skins or hides of sheep, goats, cattle and occasionally that of crocodiles and snakes are commonly used for the production of the leathers. They are obtained from slaughterhouses, markets and seldom from hunters.

There are three phases in the leather manufacturing process, namely, the pre-tanning, tanning and posttanning stages [5]. The pre-tanning phase encompasses the initial activities (soaking, liming, unhairing, deliming/ bating and fleshing) performed to prepare the skins/hides for the tanning phase. This stage involves the removal of dirt, hairs, flesh and fats from the skins leaving the collagen fibre which is the only essential part of the skins processed into leather. Moreover, during the pre-tanning phase, the fibrils making up the collagen structure are split up for easy penetration of tanning agents [11]. The pelts after undergoing the pre-tanning stage are tanned during the tanning phase into leather principally through the vegetable tanning method and occasionally, through the alum tawing technique. The post-tanning phase consists of different operations such as stretching, trimming and

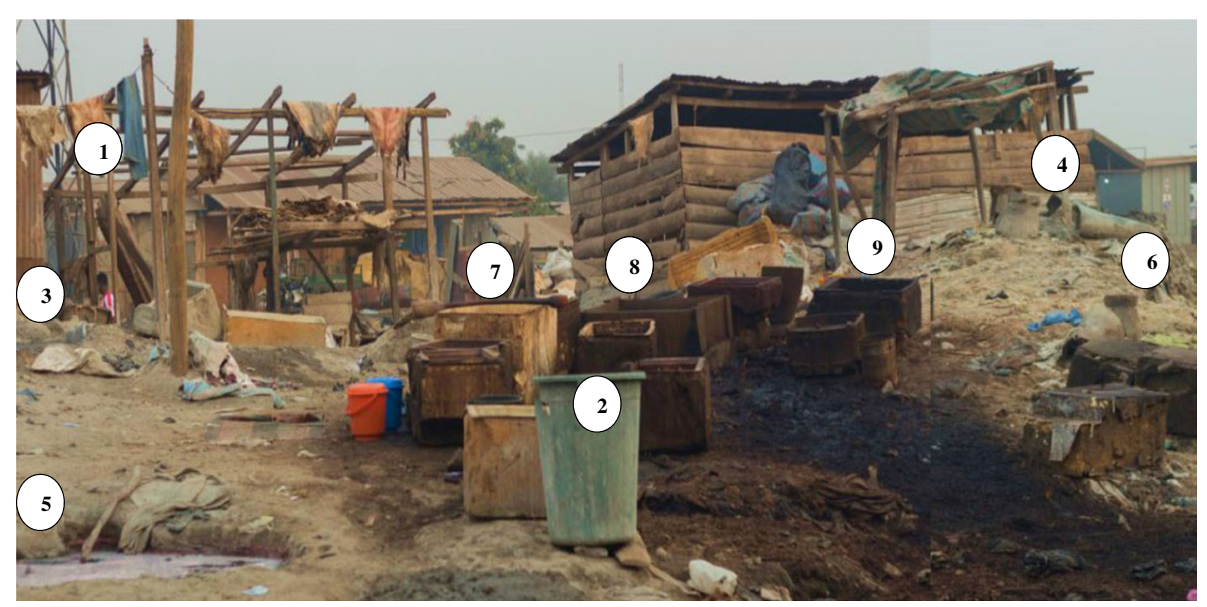

Fig. 1 Tannery site in Ashanti Region 1 Curing (drying) 2 Soaking 3 Liming 4 Unhairing 5 Deliming \& Bating 6 Fleshing 7 Vegetable tanning 8 Red dyeing 9 Black dyeing 
dyeing conducted after the tanning phase to impart certain traits such as colour and texture to the leather depending on the required specifications. These processes are also practised in modern leather manufacturing. Some other key processes such as pickling, retanning, neutralization and shaving are specifically peculiar to modern leather production. The flow of activities in artisanal leather processing in Ghana including their corresponding input materials have been illustrated in Fig. 2. The entire leather manufacturing process takes an average of 5 days. The leathers are used in the fabrication of bags, footrest cushions, belts, wallets, basket handles, sandals and skins for chiefs. Detailed descriptions of the various activities have been elaborated in the following sections. A comparison made between artisanal and modern-day leather making processes have been presented in Table 1.

\subsection{Pre-tanning phase}

\subsubsection{Curing}

Fresh, untarnished skins are required for the production of quality leather. Raw skins that cannot be processed immediately are, however, cured to prevent putrefaction. $\mathrm{Nu}$ merous microbes are originally harboured in the skins/ hides of live animals [12]. Hence, once the skins are flayed, activities of these microbes result in an immediate decay of the skins due to the high percentage of water and proteins in the skins. The decay destroys the structure of the skin making it unsuitable for leather production $[13,14]$. Among the various factors influencing decay, water activity, a term referring to the quantity of unbound water molecules in the structure of the skin which is also dependent on the moisture content of skins plays a pivotal role in supporting microbial activities $[15,16]$. Thus,

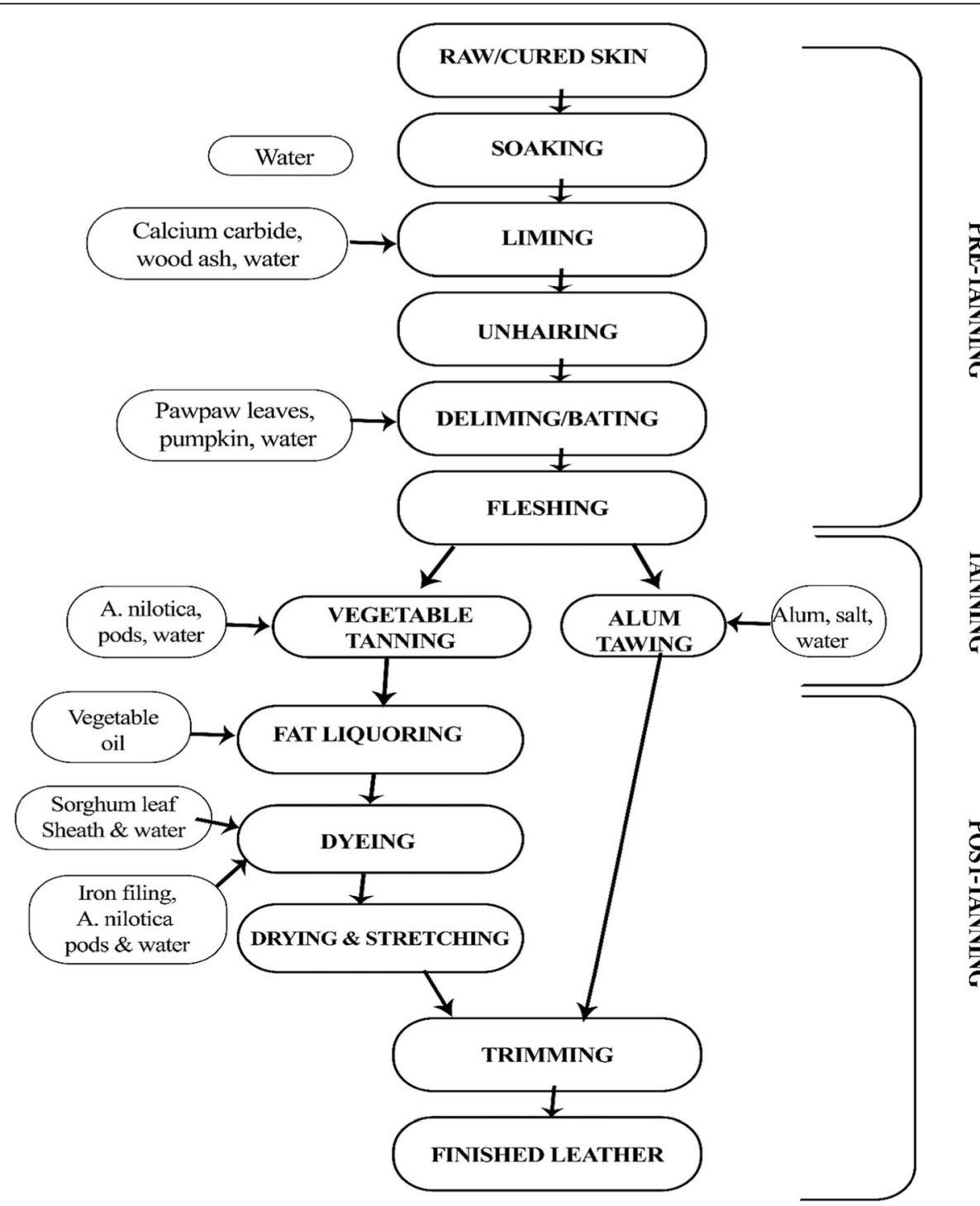

Fig. 2 Schematic diagram of artisanal leather making processes and their corresponding input materials 
Table 1 Comparison between artisanal and modern-day leather making processes

\begin{tabular}{|c|c|c|}
\hline Process & Artisanal & Modern-day \\
\hline Curing & Skins/hides are salted and then sun-dried & Skins/hides are salted or sometimes refrigerated. \\
\hline Soaking & $\begin{array}{l}\text { Skins/hides are soaked and washed in water } \\
\text { just once for about } 6 \text { to } 24 \mathrm{~h}\end{array}$ & $\begin{array}{l}\text { Skins/hides are soaked in water mixed with detergents, sodium } \\
\text { sulphide, sodium carbonate, biocides and soaking proteases. } \\
\text { Soaking may be carried out two or more times and may last } \\
5 \text { to } 10 \mathrm{~h}\end{array}$ \\
\hline Unhairing and liming & $\begin{array}{l}\text { Skins are immersed in a liming liquor composed } \\
\text { of wood ash, waste calcium carbide and water } \\
\text { for about } 12-24 \mathrm{~h} \text {. The skins are then unhaired } \\
\text { using a double-handled knife }\end{array}$ & $\begin{array}{l}\text { Skins/hides are immersed in a liming liquor made up of } \\
\text { calcium hydroxide, sodium sulphide and sodium hydrosulphide. } \\
\text { Unhairing and liming occurs simultaneously during which the } \\
\text { hairs are filtered out of the liquor (hair saving) or they dissolve } \\
\text { in the liquor (destructive unhairing) }\end{array}$ \\
\hline Fleshing & $\begin{array}{l}\text { Carried out after deliming/bating process with } \\
\text { the aid of a double-edged knife }\end{array}$ & Done with the aid of a fleshing machine \\
\hline Splitting & Not practised & $\begin{array}{l}\text { Thick skins are divided into two or more layers along the } \\
\text { longitudinal section }\end{array}$ \\
\hline Deliming and bating & $\begin{array}{l}\text { Deliming and bating occurs in a solution } \\
\text { composed of ground pawpaw leaves and } \\
\text { water or sliced pumpkin fruits in water }\end{array}$ & $\begin{array}{l}\text { A solution of ammonium chloride is commonly used for } \\
\text { deliming. Bating is achieved by applying a solution of protease } \\
\text { enzymes (usually of bacteria or animal (pancreatic) source) to } \\
\text { the pelts. }\end{array}$ \\
\hline Pickling & Not practised & $\begin{array}{l}\text { Pelts are pickled in a solution of sodium chloride, formic acid } \\
\text { and sulphuric acid. }\end{array}$ \\
\hline Tanning & $\begin{array}{l}\text { Primary form of tanning is vegetable tanning } \\
\text { using a liquor made of pounded pods of } \\
\text { Acacia nilotica and water. Alum tawing is } \\
\text { practised on a small using a solution of alum, } \\
\text { salt and water. }\end{array}$ & $\begin{array}{l}\text { Chrome tanning is extensively practised using basic chromium } \\
\text { sulphate. Other forms of tanning applied are syntans, vegetable, } \\
\text { aldehyde and other mineral tanning such as zirconium, aluminum } \\
\text { and titanium tanning. }\end{array}$ \\
\hline Sammying & Not practised & Excess water in the leathers is removed mechanically \\
\hline Chrome splitting and shaving & Not practised & Thick leathers are split into desired thickness. \\
\hline Washing & Not practised & Water containing surfactant may be used \\
\hline Retanning & Not practised & $\begin{array}{l}\text { Usually syntans, vegetable tannins and aldehydes are applied to } \\
\text { the leathers. }\end{array}$ \\
\hline Neutralisation & Not practised & Sodium acetate and sodium bicarbonate are used in the process \\
\hline \multirow[t]{3}{*}{ Dyeing } & $\begin{array}{l}\text { Dye bath of a ground sorghum leaf sheath, } \\
\text { liming liquor and water gives a deep red colour } \\
\text { to the leathers }\end{array}$ & \multirow[t]{3}{*}{ Commonly used dyes are the acid and metal complex dyes. } \\
\hline & $\begin{array}{l}\text { Black dyes are made up of a mixture of iron } \\
\text { filings and crushed pods of } A \text { nilotica. }\end{array}$ & \\
\hline & $\begin{array}{l}\text { A mixture of the red and black dyes are used } \\
\text { to produce brown leathers. }\end{array}$ & \\
\hline Fat-liquoring & Vegetable oil is used & $\begin{array}{l}\text { Sulphonated or sulphated oils are applied on the leathers in their } \\
\text { emulsified form. }\end{array}$ \\
\hline Washing & Not practised & Water is used to remove unbound chemicals from the leathers \\
\hline Drying & Leathers are dried in the sun & $\begin{array}{l}\text { Commonly dried in vacuum driers. Other drying methods employed } \\
\text { are toggle drying, radiation drying and paste drying. The leathers } \\
\text { are usually stretched during the drying process. }\end{array}$ \\
\hline Finishing & $\begin{array}{l}\text { Leathers are stretched manually and then } \\
\text { trimmed using a pair of scissors. }\end{array}$ & $\begin{array}{l}\text { Variety of finishing techniques including polishing, embossment, } \\
\text { milling, surface coating and buffing are employed. }\end{array}$ \\
\hline
\end{tabular}

methods of skin preservation are primarily aimed at reducing or eliminating the water activity of skins to hamper the activities of microbes [17].

Salting preserves the skin through two major mechanisms: dehydration and bacteriostatic effects. Application of the salt on the skin's surface increases the salt concentration on the periphery of the skin above that in the internal parts of the skin. This difference in salt concentration creates a concentration gradient between the outer and the inner parts of the skin which causes the transport of water molecules (water activity) from the inner cells of the skin to the external parts of the skin through the cell membranes via the process of osmosis. This loss of water activity from the inner cells of the skin results in the dehydration of the skin which slows down decay $[12,16]$. 
In addition to the expulsion of the water activity from the salted animal skin, microbial cells occurring in and on the skin, which are responsible for skin decay are also destroyed through the osmotic loss of water from their cells. The expulsion of water from the microbial cells has a bacteriostatic effect on the microbes through cell destruction, retardation of growth and subsequent death. In this way, the possible putrefaction of the skin slows down or is eliminated $[12,16]$. Despite its effectiveness, the salting method is accompanied by the release of large quantities of chloride and sodium ions which pollutes the environment [18].

The sun-drying method, a very simple and low-cost technology [15] employed by the tanners involves the spreading of the skin on the ground or hanging them on ropes in the open which exposes the surface of the skin to direct sunlight. During drying, part of the heat energy from the sun is absorbed by the skin and the other portion of the sun's rays are reflected [19]. The absorbed heat energy heats up the moisture on the surface of the skin and converts it to water vapour which is then lost to the atmosphere through evaporation. The moisture content on the periphery of the skin thus decreases. This dried surface of the skin and the moisturized interior parts of the skin create a difference in moisture concentration which causes the moisture in the interior parts of the skin to move to the exterior parts via diffusion. Once on the surface, the water molecules are again heated by the sun's rays and converted to water vapour which then evaporates [20]. Through this mechanism, the skin dries up. During the drying process, wind plays a very crucial role by blowing away water vapour which saturates the atmosphere around the skin, thereby ensuring a vapour pressure gradient between the atmosphere and the surface of the skin. This vapour pressure difference facilitates evaporation [17]. The loss of moisture or water activity from the skin limits the activities and growth of pathogens on the skin which hampers degeneration of the skins $[15,17]$.

\subsubsection{Soaking}

The initial stage in the leather making process is the soaking stage during which the skins are left immersed in pots, barrels or buckets of water and washed manually. The skins are soaked only once and may last from 6 to $24 \mathrm{~h}$ depending on their sizes and the extent of dryness. The soaking liquor usually has a $\mathrm{pH}$ of 7 . The washing rids the skins of dirt, dung, blood and any preservatives (salt). According to Queirós et al. [21] the other relevance of the process is the restoration of moisture in cured skins/hides. During the process, water molecules are reabsorbed into the skins through the osmotic phenomenon. The rehydration of the skins widens the pores of the skin fibres which facilitates easy absorption and uniform distribution of the chemicals that would be applied in the subsequent steps [11]. The skins after being soaked become more flexible and workable. However, the wastewater discharged would contain huge loads of sodium and chloride ions since the salts are not recycled prior to the soaking process.

In modern-day leather fabrication, the soaking process is performed two or more times in drums and may take a duration of $5-10 \mathrm{~h} \mathrm{[11]}$. The soaking liquor also with a $\mathrm{pH}$ of 7 [11] is prepared by the mixing some other chemicals such as detergents, sodium sulphide, sodium carbonate, biocides and soaking proteases in water. Detergents aid in dampening the skin's surface to hasten the rehydration process, sodium sulphide or sodium carbonate enhances water uptake by the skins, proteases digest the nonstructural proteins to improve the rehydration process and biocides hinder microbial activities to prevent possible skin decay during soaking [3]. Prior to the soaking stage, the skin/hides may be desalted to recover the salts which may be reused or thrown away. Desalting may be achieved by either shaking of the salts from the skins/hides manually or by using desalters [5].

\subsubsection{Unhairing}

Following the loosening of the hair shafts on the animal skin during the liming stage, the tanners with the aid of a blunt side of a double-handled knife completely scrape of the hairs/wool from the skins. The importance of the hair removal is to make the skin highly permeable to the tanning agents which would be applied during the tanning phase [3]. The recovered hair in artisanal leather making is, however, discarded even though it can be put to other useful purposes such as animal feed and adsorbents. The keratin protein can be extracted for manufacturing biomedical products [22].

In industrialised tanneries, the two main unhairing techniques employed are hair burning or hair saving. Hair burning has been the traditional method of unhairing during which the liming stage is carried out simultaneously with the unhairing process. Here, the pelts are immersed in a solution of calcium hydroxide and sodium sulphide in closed drums. During the process, the hairs dissolve leading to the generation of high pollutant loads which are very toxic and odorous. The hair saving method, a cleaner technology used in modern times permits the hairs to be removed rather than been destroyed. The process aims at loosening the hairs at their roots which decreases the frictional forces keeping the hairs within the follicles. The hairs are recovered through a filtering system immediately after being loosened in order to prevent a complete destruction of the hairs due to the addition of sodium sulphide. There are different techniques under the hair saving method such as enzymatic unhairing (application of proteolytic enzymes from 
bacterial sources and sodium sulphide to the pelts which degrade the epidermis of the skin and loosens the hairs for easy removal), unhairing with organic sulphur compounds (usage of organic sulphur compounds meant to break down the epidermis and hair roots and sodium sulphide/sodium hydrosulphide for loosening the hairs) and lime-sulphide hair saving method (utilization of lesser concentration of sodium sulphide to loosen the hairs and lime to immunize the hairs). Removal of short hairs which still stick in the skin after the hair saving process can be achieved through reliming. Sometimes sodium sulphide may be added to dissolve the hairs [23].

\subsubsection{Liming}

The soaking process is followed by the liming stage. The essence of this stage is to loosen the hair roots in the skin for easy removal of the hairs. During the process, the soaked skins are placed in an alkaline medium consisting of wood ash, waste calcium carbide and water. The mixture is prepared in lined-up circular pits or big clay pots. The wood ash, sourced from bakeries or domestic and commercial cooking facilities, is generated from the burning of firewood and charcoal. Calcium carbide waste on the other hand, is obtained from a welding industry. The proportions of the constituents of the lime solution are uncalculated but rather based on the discretion of the tanners. The $\mathrm{pH}$ of the liquor is however, usually between 12 and 13 . The skins are immersed in the liming solution for a period ranging between 12 to $24 \mathrm{~h}$ depending on their toughness or thickness. The tougher the skin/hide (as in the case of goats) the longer the duration. The liming solution is not discarded after use. Rather additional quantities of wood ash and waste carbide are added to the original solution whenever necessary to reactivate and enhance its effectiveness. The liming liquor is only discharged when left unused for about two or more weeks.

Materials used in traditional leather making varies among countries. In Northeastern Nigeria, Zaruwa \& Kwaghe [8] reported the use of potash and powdery burnt cow bones (high calcium content) mixed in water to obtain the liming solution. According to Skinner, [24] the liming liquor used by artisanal tanners in Central Sudan is composed of powdered burnt limestone and water. Traditional tanneries in Ethiopia according to Gebremichael [6] also uses wood ash and carbide waste mixed in water [9]. In modern leather processing, a liming solution comprising of water, calcium hydroxide and sometimes sodium sulphide is applied to the pelts for a duration of about $18 \mathrm{~h}[3,18]$.

Wood ash, predominantly composed of oxides and hydroxides of the calcium element is highly alkaline with a $\mathrm{pH}$ of about 12. Other alkali-earth metals present are potassium, magnesium and silicon [25-27]. The calcium oxide $(\mathrm{CaO})$, also known as quicklime, dissolves in water to produce calcium hydroxide, $\mathrm{Ca}(\mathrm{OH})_{2}$ (slaked lime) according to the chemical Eq. (1).

$$
\mathrm{CaO}_{(s)}+\mathrm{H}_{2} \mathrm{O}_{(l)} \rightarrow \mathrm{Ca}(\mathrm{OH})_{2(a q)}
$$

The calcium carbide $\left(\mathrm{CaC}_{2}\right)$ residue also termed as carbide lime is a waste material generated during acetylene gas production. It is also characterised by high alkalinity with a $\mathrm{pH}$ value usually higher than 12 . The high alkalinity is due to its large composition of calcium hydroxide ( $85-95 \%$ by mass). The remaining fraction of the calcium carbide is made up of $1-10 \%$ of calcium carbonate, $1-3 \%$ of carbon and silicates. Calcium carbide dissolves in water to produce calcium hydroxide and acetylene gas $\left(\mathrm{C}_{2} \mathrm{H}_{2}\right)$ [28-30] according to Eq. (2).

$$
\mathrm{CaC}_{2(s)}+2 \mathrm{H}_{2} \mathrm{O}_{(l)} \rightarrow \mathrm{C}_{2} \mathrm{H}_{2(g)}+\mathrm{Ca}(\mathrm{OH})_{2(a q)}
$$

The calcium hydroxide produced from the wood ash and calcium carbide in solution is sparingly soluble in an aqueous medium having a solubility of $1.2 \mathrm{~g} / \mathrm{L}$ at $25^{\circ} \mathrm{C}$. It ionizes into calcium and hydroxide ions as shown in Eq. (3). The occurrence of the hydroxide ions gives the liming solution its alkaline attribute [31]. Calcium hydroxide is preferably used due to its poor dissolution in water as this enables the $\mathrm{pH}$ of the mixture to be stabilized within a range of $12.5-12.8[18,31]$. The mixture of the wood ash and calcium carbide in water is done in such a way that, part of the lime (calcium hydroxide) produced dissolves whilst the excess amount after saturation is reached remains undissolved in the solution. In this way, as the skin absorbs some of the dissolved lime, the excess amount dissolves to maintain equilibrium [32].

$$
\mathrm{Ca}(\mathrm{OH})_{2(s)} \leftrightarrow \mathrm{Ca}_{(a q)}^{2+}+2 \mathrm{OH}_{(a q)}^{-}
$$

Immersion of the animal skin in the highly alkaline lime mixture has a hydrolytic effect on the non-structural proteins, namely, the globulins and albumins. At the same time, collagen fibres in the dermis swell and open up making it possible for the lime to attack and breakdown the protein, keratin in the hair follicles. In this way, the hair shafts become loose at their roots facilitating their easy and fast removal. The decomposition of the hair follicles is accompanied by the simultaneous release of sulphur compounds from the keratin protein. These sulphur compounds also aid in hastening the decomposition process. Additionally, the lime the epidermis of the skin decomposes and the adipose tissues on the animal's skin are hydrolysed into lime soap through the process of saponification. The liming process is the most essential step which results in a split up of the collagen fibrils to enhance the uptake of process chemicals (such as oils applied during the fatliquoring stage) $[18,32,33]$. 


\subsubsection{Deliming and bating}

Deliming and bating come after the unhairing stage. In this stage, a bating solution is prepared in pots or cemented circular pits. The constituents of the solution are usually pounded pawpaw leaves mixed with water or cut-up pumpkin fruits mixed in the spent soaking liquor that was generated during the soaking stage. Other tanneries also mix up both the pounded pawpaw leaves, cut-up pumpkins and the soaking liquor. The bating liquor has a $\mathrm{pH}$ within the ranges of 8 and 9. The hairless skins are drenched in the deliming/bating solution and left for about 4 to $24 \mathrm{~h}$ depending on the strength of the liquor. Exceeding the time limit for bating can lead to the creation of holes in the pelts. The bating liquor is not discarded after use but rather used to treat an uncountable number of skins. The liquor is recharged from time to time by further addition of either ground pawpaw leaves or sliced pumpkin fruits. On very few occasions, debris composed largely of hair, soil particles and flesh which tend to settle at the bottom of the pits is scooped out.

The deliming/bating liquor serves two major purposes: removal of lime from the skins and enzymatic breakdown of the proteinaceous substances in the skins. During the liming operation, some amount of lime is absorbed into the pelts. Thus, $\mathrm{pH}$ of the pelts rises to ranges usually between 12.5 and 13 [18]. In order to make the next step, the bating process effective, the $\mathrm{pH}$ of the pelt must be decreased to levels between 8.5 and $9[1,18]$. This reduction in $\mathrm{pH}$ is realized during the deliming stage when the absorbed lime diffuses out of the skins into the deliming/bating liquor. The deliming process also deswells the swollen pelts partially. It must be added that deliming in modern leather making is performed by applying ammonium chloride solution to the pelts in closed drums [18]. The ammonium salt is capable of immediately reducing the $\mathrm{pH}$ of the pelts to the required ranges within 8.5 and 9 [11].

The skins after being delimed are bated. In artisanal leather making, the deliming and bating processes occur in the same liquor. The ground pawpaw leaves and pumpkin fruits which are used in the preparation of the liquor contain proteolytic enzymes and these acts as bating agents [34-36]. The enzyme in the pawpaw leaves is specifically known as papain [36]. The pounding of the pawpaw leaves and the cutting up of the pumpkin fruits are done to extract intracellular products which include these proteolytic enzymes [37]. The enzymes serve as bating agents by hydrolysing the peptide bonds of complex proteins (which constitute the flesh on the animal's skin) into shorter chains of peptides and amino acids. These enzymes also digest amino acids, fats and esters [36, 38, 39]. The complex proteins which are broken down during the bating stage include the keratin, globulins, albumins, elastin and cells. Only the collagen fibre remains unaffected. The $\mathrm{pH}$ of the bating liquor which is within the ranges of 8.0 and 9.0 is the optimum working range for these proteolytic enzymes [18].

The soaking liquor is used by some of the tanners as part of the bating solution because it contains blood and animal dung which were washed from the raw animal skins. Blood and animal dung are also known to contain proteolytic enzymes which break down long-chain proteins of the animal flesh into much simpler forms. There are numerous microorganisms which include Providencia stuartii and Bacillus cereus [40] in animal dung that are responsible for the production of these proteolytic enzymes [41-43]. Due to the strong activity of these enzymes, exceeding the bating duration can lead to the destruction of the collagen fibre (by punching holes in the fibre) rendering the pelt unsuitable for leather manufacturing [18].

Aside the use of pawpaw leaves and pumpkin fruits as bating agents, traditional tanners may also use bird droppings $[8,24]$ and urine of cows [6] as practised in Nigeria and Ethiopia respectively. In contrast, modern tanners employ enzymes such as trypsin and alkaline protease for bating the skins [3].

After bating, the pores in the pelt are widely opened up making them more penetrable to absorb the tanning agents that will be applied in the next production stage. Bating also makes the skin soft, supple and more workable [1,33].

\subsubsection{Fleshing}

Upon the loosening of the flesh and fats on the skin after bating, the tanners with very little effort scrape off the flesh and fats using the sharp edge of the doublehandled knife. Depending on the size of the skin, fleshing can take 5 to $30 \mathrm{~min}$ to complete. Longer periods are required for fleshing the hides of cattle. Fleshing machines are however, available in industrial tanneries to simply carry out the task [1].

However, the traditional method of fleshing is inefficient as some pieces flesh and fatty tissues still remains on the skins even after fleshing. In a study conducted by Boahin et al. [9] traces of flesh were found on finished leathers after careful observation under a microscope. The leathers soon started to produce putrid odour when kept under humid conditions due to decomposition of the flesh.

Fleshing is an essential step done to remove the unwanted flesh and fats from the pelts which exposes the collagen fibre for the tanning phase [18]. The collagen is the most abundant protein in mammalian skins. It constitutes about 25 to $30 \%$ of the skin structure [44]. The collagen comprises three polypeptide strands which have been twisted around one another into a three-helical 
structure termed as tropocollagen [45, 46]. There are about a thousand amino acids constituting the protein collagen. However, the most occurring ones are glycine, proline and hydroproline [47]. The tropocollagen macromolecules bond to other tropocollagen macromolecules to form fibrils which in turn are also bonded to other fibrils to form the collagen fibre $[45,46]$. This special formation of the collagen fibre makes it mechanically strong with a good tensile strength [45]. This structural strength of the collagen coupled with its high abundance in the animal skin makes it suitable for leather production. The fleshings can be processed for the production of other products such as adhesives, biogas, animal feed and lubricants [48] even though it is currently not being reused.

\subsubsection{Washing}

After the fleshing process, the pelts are washed either in water or spent tanning liquor. The spent tanning solution is composed of a mixture of ground pods of Acacia nilotica and water. The washing is done to cleanse the pelts from awful smells and any debris gathered on the pelts during the bating process.

This is the first time the skins are washed in the traditional leather making process. However, in modern leather processing, the skins are washed after each process stage to remove residual chemicals. The infrequent washing of the skins in artisanal leather making contributes to the smelly nature of the leathers produced [9]. The tanners attribute the inadequate washing of the skins to the scanty water available for leather making.

\subsection{Tanning phase}

The next phase in the leather production process is the tanning stage. The main tanning technique employed is vegetable tanning. Alum tawing is also performed but only on a very minimal scale because the customer demand for alum-tawed leathers is very low due to their white colouration which gets easily dirtied and discoloured. Those that are made are primarily requested for by traditional or fetish priests.

\subsubsection{Vegetable tanning}

Vegetable tanning of the pelts is executed in big clay pots or in plastic containers filled with a mixture of pounded pods of Acacia nilotica and water. The pelts are tanned for a period of time between 3 to $24 \mathrm{~h}$ and then dried. After tanning, the leathers attain a light brown hue.

The pods of Acacia nilotica (also known as Gum Arabic in English, Bagaruwa in Hausa [49], Babhul in Hindi and Babool Baum in German [50]) is widely used as the primary source of tanning agent by artisanal tanners in various countries including Nigeria [8], Sudan
[24] and Ethiopia [6]. On the other hand, the principal tanning agent used in industrial leather making is chromium sulphate [1]. Other types of tanning agents employed in industrial tanneries are the aldehydes, syntans, vegetable, titanium and zirconium salts [51].

In modern leather processing, the tanning stage is preceded by pickling. The pelts are pickled in a solution of water, acids (sulphuric acid and formic acid) and salt (sodium chloride). The relevance of pickling is to condition the pelts to meet the requirement desirable for tanning. The acids acidify the pelts to a $\mathrm{pH}$ of $2.5-3$ and also protonate the carboxyl ions on the collagen fibre thereby fostering the chemical reaction that would occur between chromium sulphate and the carboxyl ions. The salts are to avert or reverse acid swelling of the pelts which can otherwise cause permanent damage to the pelts. Beside enhancing the reactivity of the chromium sulphate with the collagen fibre, pickling also prevents putrefaction of the pelts during storage or transportation [11].

One major advantage of the use of vegetable tannins over chrome and other types of mineral tannins is the less pollution load associated with it. Whilst Acacia nilotica constitute a biodegradable waste, the chromium salt used in modern tanning is highly toxic to both environmental and human health. This makes the use of the vegetable tannins which are more ecologically friendly [52]. Moreover, the pickling process in industrial leather processing further pollutes the environment as the sulphate ions, acids and chlorides add to the pollution load generated during manufacturing process.

The acacia pods contain tannins [53]. These tannins are polyphenolic compounds which are acidic in nature [54]. Generally, tannins are classified as being either hydrolysable or condensed. Hydrolysable tannins are compounds bearing glucose or other sugar alcohols at their centre. When these sugars are chemically bonded to gallic acids, they are known as gallotannins and when bonded to hexahydroxydiphenic acid, they are referred to as ellagitannins. Condensed tannins, on the other hand, are basically constituted by flavan-3-ols. Commonly known condensed tannins are the catechins and the epicatechins. The tannins in Acacia nilotica is a combination of both hydrolysable and condensed tannins in which gallic acids and flavanols are held together by ester bonds $[55,56]$.

The tannin content in the matured pods of Acacia nilotica ranges between 12 and 20\% [53]. Concentration of tannins as high as $30 \%$ in A. nilotica has also been reported by Musa and Gasmelseed [56]. Pounding of the pods into smaller particle sizes releases the tannins which are primarily contained in the husk and the resulting grain powder. The tannin content in the husk is approximately $12 \%$, whilst that in the grain powder is about 55\% [56]. Mixing the pounded pods with water which is a polar solvent extracts the tannins [54]. 
On immersion of the pelt in the tanning solution, the tannins are absorbed into the collagen material. The compounds making up the tannins bind to the proteins in the collagen through hydrogen and covalent bonding [57]. The hydroxyl groups of the phenolic compounds in the tannins form hydrogen bonds with the carboxyl, amine and amide groups on the collagen material [58].

Averagely, the tanning liquor has a $\mathrm{pH}$ of 6 which is within the optimum $\mathrm{pH}$ range of 4 and 6 for effective penetration of the tannins into pelts [53]. The tannins also function both as a tanning agent and a dye [50]. As tanning agents, the tannins $\tan$ the pelt into leather. Whilst as a dye, the tannins impart a light brown [54, 59] hue to the leather. The tannins in Acacia nilotica are considered a suitable tanning agent capable of producing good quality leather with high tensile strength, tearing strength, grain crack, shrinkage temperature, and flexing endurance [60]. There is however, a dearth in knowledge regarding the properties of indigenous leathers produced in Ghana.

\subsubsection{Alum Tawing}

Alum tawing as the name implies utilizes aluminum sulphate (alum) as its principal tanning agent. The tanning liquor is however, a mixture of water, alum and salt. The skins or pelts to be tanned are rinsed in the liquor and then left immersed for about $48 \mathrm{~h}$. The skins or pelts which attain a whitish colouration after tanning are then dried.

During alum tannage, aluminum ions $\left(\mathrm{Al}^{3+}\right)$ produced from the dissociation of the alum form cross-linkages with the collagen fibre. The ions through electrostatic bonding with the carboxyl groups on the collagen form complexes of aluminum which possesses high molecular weight. These bonds are, however, weak. Hence, the alum tannage fades out readily from the leather, particularly when in contact with water [61-63].

Alum dissolves in water to produce aluminum hydroxide and sulphuric acid as shown in Eq. (4). Thus, the alum tawing liquor is acidic [11] with an average $\mathrm{pH}$ of 4.5. According to Covington [51], aluminum ions are stable at this $\mathrm{pH}$ value of 4 .

$$
\begin{aligned}
& \mathrm{Al}_{2}\left(\mathrm{SO}_{4}\right)_{3(s)}+6 \mathrm{H}_{2} \mathrm{O}_{(l)} \rightleftharpoons 2 \mathrm{Al}(\mathrm{OH})_{3(s)} \\
& \quad+3 \mathrm{H}_{2} \mathrm{SO}_{4(a q)}
\end{aligned}
$$

The collagen in this acidic medium tends to swell through the osmotic uptake of water, a phenomenon termed as acid swelling [64]. The water molecules form hydrogen bonds with the amino acid groups in the collagen. Acid swelling of the pelt is, however, undesirable for the production of quality leather. Salt is, therefore, added to the tawing liquor to suppress plumping of the pelt. It does this by breaking the hydrogen bonds between the water molecules and the collagen protein. Aside detaching water from the collagen fibre, the salt also tends to enlarge the pores and the surface area of the collagen fibres which enhance absorption of the alum into the pelt [65]. During alum-tawing, the alum tans the pelts [66] and at the same time imparts a white colouration to them.

\subsection{Post tanning phase \\ 2.3.1 Fat liquoring}

Fat liquoring is a common activity in both artisanal and industrial leather making. The lubricant used by most artisanal tanners is mostly from plant sources. These include groundnut oil, palm kernel oil (Ghana), African Mahogany seed oil (Nigeria), natal rhus oil (Ethiopia) and sesame oil (Sudan) $[6-8,24]$. The oil is simply rubbed on the surface of the leather with a piece of cloth by the artisans. It adheres to the surface and also penetrates into the inner fibres of the leather [1] and enhances the smoothness, tenderness and shine of the leather as well as its resistibility to water, dampness, chemicals, tension and scratches [3]. The lubrication also prevent the fibres from sticking to each other after drying [11].

Industrial tanners on the other hand, do not depend on oils or fats solely from plants but also from other sources including fishes such as sardine, waxes from bees and others like paraffin oils [67]. Contrary to the application of raw oils on the leather surfaces as done in artisanal leather making, industrial tanners use the oils in their emulsified form to ensure good penetration of the oils into the leather fibre [67]. According to Santos [67] the disadvantage of applying the oils in their raw state is that it simply greases the leather surface and thus the full effect of oiling on the leathers is not achieved.

It must, however, be noted that in modern leather manufacturing fat liquoring is preceded by other wet processes: neutralization and retanning which are not performed in artisanal leather making. The leathers obtain a low $\mathrm{pH}$ of about 4 after chrome-tanning which can interfere with their bonding reactions with dyes and other process chemicals. Hence, the leathers are taken through a neutralization process during which they are drenched for about $30 \mathrm{~min}$ in mild alkali solutions of sodium acetate and sodium bicarbonate to neutralise the absorbed acids [3, 68]. The neutralisation process also prevents destruction of the leather during drying [1].

Retanning involves the utilisation of chemicals such as mineral, aldehydic and synthetic tanning agents on the tanned pelt to confer additional properties to the leather. The purpose for retanning is to improve the hydrothermal stability, dye fixation, handling and colour properties of the leather [11]. 


\subsubsection{Dyeing}

The original light brown colour of the leathers obtained after vegetable tanning may be maintained. Otherwise, they may be dyed into other colours specifically black, dark brown or red. The dyes employed in artisanal tanning are usually plant-sourced. Some plant parts are capable of imparting a unique colouration to leather. For instance, millet husk impart a brown hue to leathers [7], sorghum plants yield a red colouration [8] and Phyllanthus amarus commonly referred to as gale of the wind, gives a blue-black colour [8]. Even though the use of plant-based dyes are environmentally friendly, the colours are usually very dull and easily fade upon exposure to sunlight and excessive handling [69].

Industrially, artificial dyes particularly, simple acid dyes and metal complexes are mostly utilized due to their relatively good fastness to light, low-production cost and wide variation of colours [70]. However, unlike natural dyes which are non-toxic, most of these synthetic dyes are carcinogenic and mutagenic and are thus, detrimental to both humans and the environment [68, 71]. Elaboration on the different dyeing techniques utilized in Ghanaian tanneries has been made in the subsequent sections.

2.3.2.1 Black dyeing The black dye liquor is prepared from the combination of iron filings or metallic iron scraps, water and $A$. nilotica pods. In some tanneries, a small number of pineapple peels or cut-up pieces of lime may also be included in the dye bath. This dye solution is not discarded. Occasionally, the settled sludge consisting of the acacia pods and the iron filings are scooped out of the pots and discharged at the tanneries. New iron filings and ground acacia pods are then mixed in the old liquor to restrengthen it. The leathers are dipped into the liquor for approximately 5 to $10 \mathrm{~min}$. They are then squeezed and sun-dried.

It is well known that metallic iron in the presence of water and oxygen corrodes to form rust $\left(\mathrm{Fe}_{2} \mathrm{O}_{3} \cdot \mathrm{H}_{2} \mathrm{O}\right)$ according to Eq. (5) [72].

$$
4 \mathrm{Fe}_{(s)}+2 \mathrm{H}_{2} \mathrm{O}_{(l)}+3 \mathrm{O}_{2(g)} \rightarrow 2 \mathrm{Fe}_{2} \mathrm{O}_{3} \cdot \mathrm{H}_{2} \mathrm{O}_{(s)}
$$

The rate of corrosion is sped up at lower $\mathrm{pH}$ [72-74] which is achieved by the inclusion of the pineapple peels, the acacia pods or the lime. The pineapple peels $(\mathrm{pH}$ : 3.4-4.2) [75] and lime (pH:1.8-2.0) [76] are citrus fruits containing different kinds of acids with citric acid making up about 80 to $90 \%$ of the total amount of acid. The other acids present are: oxalic, tartaric, formic and malic acids. The acids are released into the dye bath when these citrus fruits are added to the liquor which reduces the $\mathrm{pH}$ of the medium and consequently increases the rate of corrosion of the iron filings [72, 73]. The acacia pods also releases tannic acid into the liquor.

The rust formed on the iron filings or metallic iron scraps then reacts with the tannic acids. The chemical reaction between ferric iron generated from the rust and tannic acids is a complex one leading to the production of black precipitates known as ferric tannate. The black precipitates turn the liquor to a bluish-black colour and eventually becomes black with time resulting in the black dye liquor. This reaction is known to occur at $\mathrm{pH}$ ranging from 4 to $6[77,78]$. The $\mathrm{pH}$ of the black dye liquor is approximately 5.7 .

The ferric tannate which forms part of the solid waste generated from the production of the black dye can be recycled and reused. According to Zhang [79] ferric tannate has a high adsorption capacity for ammonium and nitrite and can therefore, be utilized for effective treatment of wastewater laden with nitrogenous substances.

2.3.2.2 Red dyeing The red dye solution is composed of pounded leaf sheaths of sorghum mixed with a small volume of the liming liquor in water. On very few occasions, the tanners may also produce light red coloured leathers by initially soaking the leather in the red dye bath and then immersing it in another bucket of water which contains cut-up pieces of lime fruit. The red dye liquor is discharged right on the tannery floor immediately after it is spent.

The red dyed leathers are known to easily discolour particularly when exposed to the sunlight [80]. Thus, in order to enhance penetrability of the dye, the leathers, prior to being dyed are initially soaked in water for 30 min and then pounded to make them softer.

The sorghum leaf sheath used in the production of red dye liquor has a naturally distinctive deep red colour due to the presence of some red pigments known as anthocyanins [81, 82]. Anthocyanins also appear as other colours such as purple and blue in some other plants like blueberries. Being a polyphenolic compound, anthocyanins are glycosides of polyhydroxy and polymethoxy compounds attached to flavylium cations $\left(\mathrm{C}_{15} \mathrm{H}_{11} \mathrm{O}^{+}\right)$. These flavylium cations which have a C6-C3-C6 skeletal structure form the central part of anthocyanins. The glycosides are mainly composed of sugars such as glucose, arabinose and xylose [83-85]. Hydroxyl and methoxyl compounds present in the structure of anthocyanins dictate the degree and the colour of the anthocyanins; such that the prevalence of the methoxyl compounds over the hydroxyl groups imparts a reddish hue [85] as it found in the sorghum leaf sheath. Amongst the various diversities of anthocyanins discovered in nature, the four commonest types appearing in sorghum are the luteolinidin, apigeninidin, 5-Methoxyluteolinidin, 7Methoxyapigeninidin [86]. 
In the preparation of the red dye liquor, the purpose of mixing a small portion of the liming liquor with the pounded leaf sheaths is to provide an alkaline medium to facilitate the extraction of the red pigments in the sheaths. These pigments are the dye colourant which turn the leathers red. An alkaline medium yields a better extraction of the pigments than raw water [87].

The lime fruit (a highly acidic fruit) used together with the red dye liquor serves as a post-mordant in lightening the deep red colouration [88]. Thus, its application gives the leather a faint red colour. There, however, seems to be a paucity in information regarding the bonding reactions that take place between the red dye and the leathers.

2.3.2.3 Brown dyeing The dark-brown colour is achieved by initially drenching the leather for approximately five (5) minutes in the red dye bath and afterwards in a dilution of the black dye liquor for another five (5) minutes. The leather is then squeezed to drain out excess liquid and then dried under the sun.

Unlike the colours: white, blue, yellow and red which are considered as being simple colours because they cannot be produced through the mixture of other colours, the colour brown has been categorised as being a compound colour. Thus, it can be obtained through a combination of two different colour solutions [89]. This is the method employed by the tanners in obtaining the dark-brown coloured leathers in which the red dye is mixed with the black dye.

\subsubsection{Stretching and trimming}

After dyeing and drying of the leathers, they are stretched and then trimmed. Drying in the artisanal leather making is achieved through sun-drying whilst variety of other drying methods such as vacuum drying, toggle drying, radiation drying and paste drying are employed in modern tanneries. The commonest method is, however, the vacuum drying method and it is known to produce highly resilient leathers [90].

During drying, water molecules in the leathers escape through evaporation processes. The capillary movement of the water molecules through the fibrils which constitute the leather fibres coupled with the continual loss of water from the fibres induces a reduction in the volume of the fibrils. The fibrils tend to shrink in size resulting in area loss. The leather, therefore, creases and may become hard after drying. The stretching of the leather then becomes a relevant stage to improve the quality of the leather by straightening the leather fibre, expanding the area yield and reducing the thickness and the denseness of the leather [91].

Before leathers are stretched in artisanal leather making, one edge of the leather is wound around a stick and held up by the hands. The other portion is fastened to a block of cement. The tanner then stretches the leather by dragging his foot on the surface of the leather along its length whilst pulling it up with both hands. Stretching is performed after the drying stage in artisanal leather making whilst in industrial leather production it is done simultaneously with the drying stage. Drying the leather whilst stretching causes a more permanent expansion in its area yield [91].

The last stage in the artisanal leather manufacturing process is trimming which is done using a pair of scissors to cut off unwanted portions or extensions of the leather to give it the desired shape. The trimmings are deposited at one side of the tannery floor and later burnt. They can, however, be reused in the manufacture of adsorbents [92].

In modern leather manufacturing, further finishing operations are executed to enhance the quality of the leather in terms of its appearance (colour and feel), handling and durability. The various finishing activities include: embossment, polishing, buffing (involves scraping and dusting the leather surface), milling (aimed at making the leather softer) and surface coating using dyes in order to mask any impairments and also to attain the desired specifications $[18,68]$.

\section{Further research}

An in-depth study has been made on the present state of knowledge regarding artisanal leather making in Ghana. However, there seems to be some research gaps in the field which has resulted in the production of low quality leathers and poor productivity. In the light of this, further investigations are still required in the following areas:

i. Information regarding the annual leather production, leather market, amount of raw skins/ hides processed per year as well as the number of tanneries in the country.

ii. Characterization of the various process materials and chemicals (wood ash, calcium carbide, iron filings and tannins in the acacia pods) used in artisanal leather making and their effects on the physical and chemical properties of the leather.

iii. Optimisation of the various processes involved in artisanal leather production in order to reduce cost, avoid wastage of resources, obtain good quality leathers, and increase productivity.

iv. The kinds of chemical and bonding reactions that occur between the tanning agents and the collagen material as well as that between the various dyes utilised and the leather material.

v. Alternative natural materials such as bating and tanning agents and dyes that can bring diversity in the types and qualities of leathers produced. 
vi. Innovative traditional finishing techniques to upgrade the leathers in terms of their texture, colour, appearances, versatility and quality.

vii. Enhancing the colour fastness of natural dyes on indigenous leathers.

viii. Designing and developing simple energy-saving machines for the various leather making processes to speed production and improve occupational health and safety.

ix. Identification, quantification and characterisation of the air pollutants, solid wastes and wastewater generated at the tanneries, development of appropriate treatment schemes and recycling and reuse of the waste products in order to conserve resources and protect human and environmental health. Ability to effectively manage the tannery wastes will also erase the negative connotation that leather making is a dirty profession [6] and make it more attractive to the youth which would ultimately decrease the unemployment rate in the country.

\section{Conclusion}

This is an exploratory study on artisanal leather making in Ghana defining the various processes and materials involved, attempting to explore the scientific principles underpinning the different stages of leather production and making comparison between artisanal and modernday leather manufacturing processes. The study revealed that artisanal leather making practices in Ghana have not changed significantly from the time of its commencement about a century ago. The primary advantage is that most of the process materials used in artisanal leather making are more ecologically friendly compared to those utilized in modern-day leather production. However, the quality of leathers produced through artisanal processes are quite low. Newly improved methods for production of better quality leathers of different diversities are, therefore, required. In this regard, this research can form the basis for further studies into optimization of artisanal leather production processes, finding alternative process materials, development of innovative technologies to enhance productivity and characterization and effective management of the noxious wastes associated with artisanal leather making. Finally, relevant lessons in the art and science of modern leather making processes pointed out in this study can be appropriately adopted to ameliorate the leather industry in Ghana.

\section{Acknowledgements}

This study was funded by Regional Water and Environmental Sanitation Centre Kumasi (RWESCK) at the Kwame Nkrumah University of Science and Technology, Kumasi with funding from Ghana Government through the World Bank under the Africa Centre's of Excellence project. The views expressed in this paper do not reflect those of the World Bank, Ghana Government or KNUST.

\section{Authors' contributions}

Miriam Appiah-Brempong made substantial contributions in the collection of data and the write up of the journal. Francis Momade, Helen Essandoh and Nana Yaw Asiedu contributed by conceptualizing the methodology for the data collection and critically editing the article. Samuel Dadzie assisted in the collection of data and gathering of relevant references for the study. All authors read and approved the final manuscript.

\section{Funding}

This research work was funded by the World Bank, Ghana Government, RWESCK and KNUST.

\section{Availability of data and materials}

All data generated or analysed during this study are included in this published article.

\section{Competing interests}

The authors declare that they have no competing interests.

\section{Author details}

${ }^{1}$ RWESCK, Department of Civil Engineering, College of Engineering, Kwame Nkrumah University of Science and Technology, Kumasi, Ghana. ${ }^{2}$ Department of Chemical Engineering, College of Engineering, Kwame Nkrumah University of Science and Technology, Kumasi, Ghana. ${ }^{3}$ Department of Materials Engineering, College of Engineering, Kwame Nkrumah University of Science and Technology, Kumasi, Ghana.

Received: 11 April 2020 Accepted: 20 August 2020

Published online: 09 November 2020

References

1. Kesarwani $P$, Jahan $S$, Kesarwani K. A review on leather processing. Int J Appl Res [Internet]. 2015;1:977-82 Available from: www.allresearchjournal.com.

2. Dargo H, Ayalew A. Tannery wastewater treatment: a review. Int J Emerg Trends Sci Technol. 2014;1:1488-94.

3. Sathiyamoorthy M, Selvi V, Mekonnen D, Habtamu S. Preparation of ecofriendly leather by process modifications to make pollution free tanneries. J Eng Comput Appl Sci. 2013;2:17-22.

4. Ezenwe U, Diike E, Duru M, Bello A, Ihuoma A. Technological Capability in the Nigerian Leather Industry: A Firm-Level Case Study. Nairobi: ATSP Working Paper; 2001. Report No.: 26.

5. Ramanujam RA, Ganesh R, Kandasamy J. Wastewater Treatment Technology for Tanning Industry. In: Vigneswann S, editor. Wastewater Treat Technol. II. Encyclopedia of Life Support Systems (EOLSS); 2010. p. 116-36.

6. Gebremichael B. Traditional leather processing, production and Marketing in Amhara Regional State of Ethiopia. Open Access Libr J. 2016;03:1-17 Available from: http://www.oalib.com/paper/pdf/5268122.

7. Wemegah R. Vegetable tanning in Bolgatanga: challenges and the way forward. Arts Des Stud [Internet]. 2014;16:27-37 Available from: www.iiste.org.

8. Zaruwa MZ, Kwaghe ZE. Traditional tannery and dyeing (Yirie) methods. In: Emeagwali G, Dei GJS, editors. African Indig Knowl Discip anti-colonial Educ Perspect transform Chang. Rotadam: SensePublishers; 2014. p. 29-33.

9. Boahin JOB, Asubonteng K, Adu-Gyamfi VE. Sanative measures against offensive odour that affect indigenous tanned leathers in Ghana. J Sci Technol. 2013;33:68-74.

10. Asubonteng K. Improving the quality of Ghanaian indigenous leatherwork: alternative strategies. Kumasi: KNUST; 2010.

11. Covington T. Tanning chemistry : the science of leather. Cambridge: Royal Society of Chemistry; 2009.

12. Sivabalan $V$, Jayanthi $A$. A study to reduce salt usage in preservation of skins and hides with alternate use of plant extract aRPN. J Agric Biol Sci. 2009;4: 43-8.

13. Gudro I, Valeika V, Sirvaityte J. Short term preservation of Hide using vacuum: influence on properties of Hide and of processed leather. PLoS One. 2014;9:1-9

14. Kanagaraj J, Chandra Babu NK. Alternatives to salt curing techniques - a review. J Sci Ind Res (India). 2002;61:339-48. 
15. Ujam JA, Onovoh JN, Okafor CE. Experimental evaluation of drying characteristics of Animal's Hide and Skin with different drying media. Asian J Adv Agric Res [Internet]. 2017:4:1-15 Available from: http://www. sciencedomain.org/abstract/22796.

16. Henney JE, Taylor CL, Boon CS. Strategies to reduce sodium intake, in the United States. Natl. Acad. Press. Washington, D.C.: The National Academies Press; 2010.

17. Heinz G, Hautzinger P. Meat Processing Technology-For Small- to-MediumScale Producers. RAP Publication 2007/20. Bangkok: FAO; 2007.

18. Beghetto V, Zancanaro A, Scrivanti A, Matteoli U, Pozza G. The leather industry : a chemistry insight part I : an overview of the industrial process. Sci Ca' Foscari. 2013;1:12-22.

19. Jain D, Tiwari GN. Thermal aspects of open Sun drying of various crops. Energy. 2003;28:37-54.

20. Sahdev RK, Sehrawat P, Kumar M. An experimental study on open Sun drying of vermicelli. Int J Adv Eng Serv. 2012;2:1-8.

21. Queirós Â, Silva VFM, Santos T, Crispim A. Optimization of bovine leather soaking process. Leather Footwear J. 2018;18:117-22.

22. Li Y, Guo R, Lu W, Zhu D. Research Progress on resource utilization of leather solid waste. J Leather Sci Eng Journal of Leather Sci Eng. 2019;1:1-17.

23. Frendrup W. Hair-save unhairing methods in leather prcessing; 2000

24. Skinner $L$. A visit to a traditional leather tannery in Central Sudan. Sudan Nubia. 2007;11:125-6.

25. Serafimova E, Mladenov M, Mihailova I, Pelovski Y. Study on the characteristics of waste wood ash. J Univ Chem Technol Metall. 2011:46:314 Available from: http://dl.uctm.edu/journal/node/j2011-1/3_Mladenov.pdf.

26. Augusto L, Bakker MR, Meredieu C. Wood ash applications to temperate forest ecosystems - potential benefits and drawbacks. Plant Soil. 2008;306: 181-98.

27. Pitman RM. Wood ash use in forestry - a review of the environmental impacts. Forestry. 2006;79:563-88

28. Sun H, Li Z, Bai J, Memon SA, Dong B, Fang Y, et al. Properties of chemically combusted calcium carbide residue and its influence on cement properties. Materials (Basel). 2015;8:638-51

29. Cardoso FA, Fernandes HC, Pileggi RG, Cincotto MA, John VM. Carbide lime and industrial hydrated lime characterization. Powder Technol. 2009;195: 143-9.

30. Ramasamy P, Periathamby A, Ibrahim S. Carbide sludge management in acetylene producing plants by using vacuum filtration. Waste Manag Res. 2002:20:536-40.

31. Farhad A, Mohammadi Z. Calcium hydroxide : a review. Int Dent J. 2005;55: 293-301.

32. McLaughlin GD. The role of lime in Tanning1. Ind Eng Chem. 1927;19:576 Available from: https://doi.org/10.1021/ie50209a020. American Chemical Society.

33. Choudhary RB, Jana AK, Jha MK. Enzyme technology applications in leather processing. Indian J Chem Technol. 2004;11:659-71.

34. Dąbrowska A, Szoltysik M, Babij K, Pokora M, Zambrowicz A, Chrzanowska J. Application of asian pumpkin (Cucurbita ficifolia) serine proteinase for production of biologically active peptides from casein. Acta Biochim Pol. 2013;60:117-22.

35. Spencer PW, Spencer RD. Globulin-specific Proteolytic Activity in Germinating Pumpkin Seeds as Detected by a Fluorescence Assay Method. Plant Physiol. 1974:54:925-30 Available from: http://www.pubmedcentral.nih.gov/ articlerender.fcgi?artid=366635\&tool=pmcentrez\&rendertype=abstract.

36. Lewis T, Woodward EF. Papain: the valuable latex of a delicious tropical fruit. Econ Bot. 1950;4:192-4.

37. Tigist M, Getnet B, Beza K, Endalamaw M, Lulit M, Tamirat D, et al. Extraction and Purification of Papain Enzyme From Papaya Leaf and the Phytochemical Components of the Leaf. Biotechnol Int. 2016;9:176-84 Available from: http://www.bti.org.in/wp-content/uploads/2016/09/BT19.8.1.pdf.

38. Richau KH, Kaschani F, Verdoes M, Pansuriya TC, Niessen S, Stuber K, et al. Subclassification and Biochemical Analysis of Plant Papain-Like Cysteine Proteases Displays Subfamily-Specific Characteristics1. Plant Physiol. 2012; 158:1583-99 Available from: http://www.plantphysiol.org/cgi/doi/10.1104/ pp.112.194001

39. Feijoo-Siota L, Villa TG. Native and biotechnologically engineered plant proteases with industrial applications. Food Bioprocess Technol. 2011;4: 1066-88.

40. Ogunnusi TA, Olorunfemi O. Isolation and identification of Proteolytic and Lipolytic Bacteria in cow dung and abattoir effluent from Ekiti general abattoir, Ekiti state, Nigeria. J Adv Microbiol. 2018;11:1-10.
41. Goyal M, Phutela UG. Protease Production from Biodigested Slurry of Biogas Plants : A Review. Curr Microbiol Appl Sci. 2018;7:369-79. Available from:. https://doi.org/10.20546/ijcmas.2018.701.042.

42. Ali S, Rana A, Rasool H, Masood MBE. Protease: an enzyme with Mutiple industrial applications (review ). Eur J Pharm Med Res. 2017:4:63-70.

43. Astrup T, Crookston J, Macintyre A. Proteolytic enzymes in blood. Acta Physiol Scand. 1950;21:238-49. Available from. https://doi.org/10.1111/j. 1748-1716.1950.tb00732.x.

44. Yang H, Shu Z. The extraction of collagen protein from pigskin. J Chem Pharm Res. 2014;6:683-7.

45. Uzel SGM, Buehler MJ. Nanomechanical sequencing of collagen: Tropocollagen features heterogeneous elastic properties at the Nanoscale. Integr Biol. 2009;1:437-88.

46. Cox RW, Grant RA, Horne RW. The Structure and Assembly of Collagen Fibrils: I. Native-Collagen Fibrils and their Formation from Tropocollagen. J Microsc. 1967;87:123-42 Available from: https://onlinelibrary.wiley.com/doi/ pdf/10.1111/j.1365-2818.1967.tb04498.x.

47. Friess W. Collagen - Biomaterial for Drug Delivery. Eur J Pharm Biopharm. 1998;45:113-36

48. Sundar JV, Gnanamani A, Muralidharan C, Chandrababu KN, Mandal BA. Recovery and utilization of proteinous wastes of leather making : a review. Rev Env Sci Biotechnol. 2011;10:151-63.

49. Ndamitso MM, Mustapha S, Etsuyankpa MB, Ajai Al, Mathew JT. Evaluation of chemical composition of Acacia nilotica seeds. FUW Trends Sci Technol J. 2017;2:927-31.

50. Ali A, Akhtar N, Khan BA, Khan MS, Rasul A, Zaman S-U, et al. Acacia nilotica: A plant of multipurpose medicinal uses. J Med Plants Res. 2012;6:1492-6 Available from: http://www.academicjournals.org/jmpr/abstracts/abstracts/ abstracts2012/9Mar/Alietal3.htm.

51. Covington AD. Modern tanning chemistry. Chem Soc Rev. 1997;26:111-26.

52. Duraisamy $R$, Shamena S, Berekete AK. A review of bio-tanning materials for processing of fish skin into leather. Int J Eng Trends Technol. 2016;39:10-20.

53. Kuria A, Ombui J, Onyuka A. Tannin Analysis of Selected Plants from Laikipia County, Kenya. J -Soc Leather Technol Chem. 2016;100:73-6.

54. Hussein SA. Utilization of tannins extract of Acacia seyal bark (Taleh) in Tannage of leather. J Chem Eng Process Technol. 2017:8:1-9.

55. Elgailani IEH, Ishak CY. Methods for extraction and characterization of tannins from some Acacia species of Sudan. Pakistan J Anal Environ Chem. 2016;17:43-9 Available from: http://www.ceacsu.edu.pk/Faculty/Journal.html.

56. Musa AE, Gasmelseed GA. Eco-friendly vegetable combination tanning system for production of hair-on shoe upper leather. J For Prod Ind. 2013;2:5-12.

57. Schropfer M, Meyer M. Investigations towards the binding mechanisms of vegetable tanning agents to collagen. Res J Phytochem. 2016;10:58-66.

58. Malea E, Boyatzis SC, Kehagia M. Cleaning of Tanned Leather : Testing with Infra Red Spectroscopy and SEM-EDAX. Jt Interim Meet Five ICOM-CC Work Groups Leather Relat Mater Rome. 2010:1-12.

59. Jamadar D, Sannapapamma KJ. Acacia nilotica pods : a natural dye source for textile Colouration. Int J Curr Microbiol Appl Sci. 2018;7:602-12.

60. Kuria A, Ombui J, Onyuka A, Sasia A, Kipyegon C, Kaimenyi P, et al. Quality evaluation of leathers produced by selected vegetable tanning materials from Laikipia County, Kenya. J Agric Vet Sci. 2016;9:13-7.

61. Mahdi H, Palmina K, Gurshi A, Covington D. Potential of vegetable tanning materials and basic aluminum Sulphate in Sudanese leather industry. J Eng Sci Technol. 2009:4:20-31.

62. Brown E, Dudley RL. Approach to a tanning mechanism: study of the interaction of aluminum sulfate with collagen. J Am Leather Chem Assoc. 2005;100:401-9.

63. Harlan JV, Feairheller SH. Chemistry of the crosslinking of collagen during tanning. In: Friedman M, editor. Protein Crosslink. New York: Plenum Press; 1977. p. $425-40$.

64. Bowes $\mathrm{JH}$, Kenten $\mathrm{RH}$. The swelling of collagen in alkaline solutions. 1 Swelling in solutions of sodium hydroxide. Biochem J. 1950;46:1-8.

65. Li X, Wang Y, Li J, Shi B. Effect of sodium chloride on structure of collagen Fiber network in pickling and tanning. J-Am Leather Chem Assoc. 2016;111: 230-7.

66. Gumel MS, Ali U. Preliminary investigation of a Colouring matter extract from Sorghum bicolor sheaths and its application to textile substrates. Bayero J Pure Appl Sci. 2012;5:17-9.

67. Santos LM, Gutterres M, Aquim PM, Priebe G. Influence of Fats During Leathermaking. 2nd Mercosur Congr Chem Eng. 2005:1-10. 
68. European-commission. Reference document on best available techniques for the tanning of hides and skins. 2003.

69. Boahin J, Asubonteng K, Adu-Gyamfi V. Manipulating indanthrene dye as a colourant for screen printing on indigenous veg-tanned leather in Ghana. J Sci Technol. 2014;34:65-72.

70. Vidya VG, Sadasivan V. Synthesis, characterization and applications of some azo dyes derived from various aromatic amines. Asian J Chem. 2018;30: 2049-53.

71. Piccinini P, Senaldi C, Buriova E. European survey on the presence of banned Azodyes in textiles. JRC Sci Tech Rep. 2008;1-40.

72. Oladele KS, Okoro KH. Investigation of corrosion effect of mild steel on orange juice. Afr J Biotechnol. 2011;10:3152-6 Available from: http:// academicjournals.org/journal/AJB/article-abstract/EDAE5EB27324.

73. Ahmad N, Husain MI, Kumar R, Mukherjee S, Dutta R. Comparative kinetics of corrosion rate on mild steel in various citrus juices. Int J Sci Adv Technol. 2012;2:157-63.

74. Patil DB, Sharma AR. Study on the corrosion kinetics of Iron in acid and base medium. E-J Chem. 2011;8:358-62.

75. Yapo ESS, Laurent KK, PIJ B, Kouame P, Kouakou T. Comparison of Pineapple Fruit Characteristics of Plants Propagated in Three Different Ways: By Suckers, Micropropagation and Somatic Embryogenesis. J Nutr Food Sci. 2011;01:1-8

76. Toolbox E. Food and Foodstuffs- pH Values. 2003. Available from: https://www.engineeringtoolbox.com/food-ph-d_403.html. [cited 2019 Sep 4].

77. Iglesias J. Garcia De Saldana E, Jaen JA. On the tannic acid interaction with metallic Iron. Hyperfine Interact. 2001;134:109-14.

78. Hem JD. Complexes of ferrous iron with tannic acid. US. Geol. Surv., Water Supply Papers, 1459-D. 1960;75-94. Available from: https://pubs.usgs.gov/ wsp/1459d/report.pdf.

79. Zhang R, Li L, Liu J. Synthesis and characterisation of ferric tannate as a novel porous adsorptive-catalyst for nitrogen removal from wastewater. RSC Adv. 2015;5:40785-91.

80. Boahin J, Adu-Agyem J, Peligah Y. Exploring the use of suede dye on leather. J Sci Technol. 2011;31:68-73.

81. Kayode PAP, Nout MJR, Linnemann AR, Hounhouigan JD, Berghofer E, Siebenhandl-Ehn S. Uncommonly high levels of 3-Deoxyanthocyanidins and antioxidant capacity in the leaf sheaths of dye Sorghum. J Agric Food Chem. 2011;59:1178-84.

82. Welch CR, Wu Q, Simon JE. Recent advances in anthocyanin analysis and characterization. Curr Anal Chem. 2008;4:75-101.

83. Pervaiz T, Songtao J, Faghihi F, Haider MS, Fang J. Naturally occurring anthocyanin, structure, functions and biosynthetic pathway in fruit plants. J Plant Biochem Physiol. 2017;05:1-9.

84. Ramos P, Herrera R, Moya-león MA. In: Warner LM, editor. Anthocyanins: Food Sources and Benefits to Consumer's Health. Hauppauge: Nova Science Publishers, Inc.; 2014.

85. Miguel MG. Anthocyanins: antioxidant and/ or anti-inflammatory activities. J Appl Pharm Sci. 2011;01:7-15.

86. Su X, Rhodes D, Xu J, Chen X, Davis H, Wang D, et al. Phenotypic diversity of Anthocyanins in Sorghum accessions with various pericarp pigments. J Nutr Food Sci. 2017;07:1-4.

87. Akogou FUG, Kayodé APP, den Besten HMW, Linnemann AR. Extraction methods and Food uses of a natural red colorant from dye Sorghum. J Sci Food Agric. 2018;98:361-8.

88. Zubairu A, Mshelia YM. Effects of selected Mordants on the application of natural dye from onion skin (Allium cepa). Sci Technol. 2015;5:26-32.

89. Akin J, Allardice S, Barker W, Bowes J, Clarke T, Creed W, et al. Encyclopaedia; Or, A Dictionary of Arts, Sciences, and Miscellaneous Literature; Constructed on a Plan, by which the Different Sciences and Arts are Digested Into the Form of Distinct Treatises of Systems ... [\& Supplement]. Philadelphia: Thomas Dobson, at the Stone house, no 41, South Second street; 1803. Available from: https://books.google.com.gh/ books?id=1MxCAAAAYAAJ.

90. Liu CK, Latona N, Cooke P. Effects of drying processes and fatliquoring on resiliency of leather. J Am Leather Chem Assoc. 2007;102:68-74.

91. Manich AM, De Castellar MD, González B, Ussman MH, Marsal A. Influence of leather stretching to gain area yield on its stress-relaxation behavior. J Appl Polym Sci. 2006;102:6000-8.
92. Kim H-U, Kim K-H, Chang Y-Y, Lee SM, Yang J-K. Heavy metal removal from aqueous solution by tannins immobilized on collagen. Desalin Water Treat. 2012;48:1-8.

\section{Publisher's Note}

Springer Nature remains neutral with regard to jurisdictional claims in published maps and institutional affiliations.

\section{Submit your manuscript to a SpringerOpen ${ }^{\circ}$ journal and benefit from:}

- Convenient online submission

- Rigorous peer review

- Open access: articles freely available online

High visibility within the field

- Retaining the copyright to your article

Submit your next manuscript at $\boldsymbol{\nabla}$ springeropen.com 